\title{
Transnational engagements and the future economic aspirations of Turkish-speaking young people in London
}

\begin{abstract}
Contemporary researchers indicate that the conditions of minority communities can no longer be analysed within the narrow boundaries of the host societies. Technological innovations, such as air transport and satellite systems, have prepared the necessary conditions for a grassroots transnationalism, and transnational activities among migrant communities are already well-documented. However, the existing literature on the effects of transnationalism for the second generation is quite restricted as regards identity construction. Yet, it is also important to analyse the economic effects of transnationalism on young people, especially on their future prospects. Within this context, this article discusses the effects of transnational social networks on the economic aspirations of Turkish-speaking young people, arguing that transnational activities alone could not influence young people's aspirations: the effects of transnationalism on young people's future preferences are only evident if gender, age, education degrees and father's economic status are taken into the equation.
\end{abstract}

Keywords: minority communities, transnationalism, young people, second generation migrants, mobility, socio-economic status, citizenship

Introduction

Researchers advocate that the chances of minority communities improving their conditions are increased once their dependency on the host societies is reduced. Migrants are, however, able to use their informal community links across national boundaries to engage in upwards mobility (Basch et al. 1994: 79; Portes et al. 1999: 229; Goldring, 1998: 189; Evergeti and Zontini, 2006). Technological innovations, such as air transport, long-distance telephone and satellite systems, have prepared the necessary conditions for a grassroots transnationalism, while researchers have introduced the concept of the 'transnational social field', implying a social network of people living within different political systems (Schiller et al. 1999: 356). Communities are no longer related with certain spaces, but with ones that are, instead, interconnected (Gubta and Ferguson, 1992: 9).

In that context, there has been growing academic interest in the transnationalisation of ethnic minorities in the west. Within this process, a substantial amount of research has been produced concerning transnational ethnic communities in developed countries. Contemporary researchers indicate that the conditions of minority communities can no longer be analysed within the boundaries of host societies (Cohen, 1997: 160; Vertovec, 1999: 447; Zhou, 2004: 1054). Transnational activities among migrant communities, and the implications of these, are already well documented (see the special 
issues of Ethnic and Racial Studies 22(2), produced in 1999, and 29(6) in 2006; as well as the website of the ESRC Transnational Communities Programme, at www.transcomm.ox.ac.uk).

Existing studies in relation to second generation migrants have mainly emphasised the importance of transnational networks in constructing an ethnic and/or cultural identity that counterweighed the negative effects of the host society, such as social and political exclusions and discrimination (Fernandez-Kelly and Konczal, 2005; Avc1, 2006; Louie, 2006; Reynolds, 2006). In that respect, the potential economic advantages of transnationalism for the second generation could only be possible from a utilisation of this transnationally-constructed identity (Vertovec, 2001: 11). For instance, Portes (1999) discusses the possible effects of transnationalism on second generation migrants in relation to their assimilation into the mainstream community. He argues that:

For the second generation, in particular, it [transnationalism] offers a valuable counterweight to a relentless process of acculturation that leads children, even at an early age, to abandon their parental languages and embrace unquestioningly the norms and styles of the host culture. In America, this process of acculturation carries the price of learning and interjecting one's inferior place in the social hierarchy. That sense, which along with poverty, creates the conditions for downward assimilation, is neutralised by the economic and symbolic alternatives that transnationalism makes possible. (Portes 1999: 472)

Transnational activities might provide great opportunities to ethnic minorities for their present survival (Portes, 2001). In relation to the younger generation, transnational alternatives might be understood as an alternative identity construction. On the other hand, it is especially important to explore the potential of transnationalism to contribute to young people's economic prospects. We need to understand whether transnational networks can make a positive contribution in the future to young people's adult life. In other words, it is worth exploring the effects of their transnational engagement on their economic aspirations.

In this respect, the following paper will discuss transnationalism in relation to Turkish-speaking young people in London and how transnational social activities might have an effect on young people's future economic expectations.

Itzigsohn et al. (1999: 318) describe the activities of migrants in a 'transnational social field' as covering many engagements from their economic interactions to their political behaviour and through to their individual and group identities. Furthermore, the access of ethnic minority groups to their own media has particular importance (Howell, 1992: 240; Gillespie, 1995: 360.). Transnational activities involve various activities from money exchange to political lobbying, but in this article we concentrate on young people's regular contact with their relatives living in different countries and on their access to Turkish television through satellite dishes.

Young people's contacts with their relatives and their viewing of Turkish television are important. Through these engagements, young people may obtain important information about transnational labour market opportunities, making them more hopeful for the future. Vertovec (2002: 3) argues that social networks are crucial in finding jobs and accommodation and in the provision of economic information to migrants. We 
analyse here how important such networks are for the second generation. By doing so, we define the effect of transnational activities on young people's future economic expectations.

The article is based on a research study conducted in north London in 2002. A mixed methodology was used. In the first stage, there was a questionnaire survey covering a range of issues from young people's current experiences to their future aspirations. The questionnaires were prepared both in Turkish and in English, respondents choosing one of them. The questionnaires were circulated at local female and male football clubs, coffee shops, community organisations, one college and one employment agency. The survey thus provided us with a basis for obtaining a targeted sub-sample for in-depth interviewing. At the end of the survey, we had 250 responses ( 78 females and 172 males aged between 16 and 23) out of 800 questionnaires circulated. ${ }^{1}$ In the second stage, we conducted thirty in-depth interviews (fifteen females and fifteen males) in order to analyse more deeply the reasons behind some repeated patterns in the survey, following which we interviewed the parents of six interviewees. All these interviews were recorded. Some of the interviews were conducted in Turkish and some in English and, on other occasions, both languages were used in the one interview. Later, we shared our draft results with three organisations: Haringey Council; an employment agency; and a community organisation. We also sent a one-page summary to fifty young people in order to get their responses. Three focus groups involving twelve of these young people were conducted at the final stage of our fieldwork. The data in the following sections are a part of this research.

This article is made up of two parts. In the first part, we define young people's engagement with the transnational social field through their contacts with relatives beyond Britain and through their access to Turkish television. In the second part, we discuss any possible relationship between transnational activities and young people's future economic plans. We argue that transnational engagements alone are not necessarily linked to the economic aspirations of young people: there are many factors, such as gender, class, length of time of living in Britain, educational qualifications, etc., which influence young people's economic aspirations and their employment plans for the future.

\section{The extent of transnational activities among young people}

There are officially three million, and unofficially five million, Turkish people living in the EU (Uras, 2002). The number of Turkish people living in Britain is estimated at between 80000 and 150 000, the majority of whom live in London (Enneli et al. 2005; Sen et al. 2008). In addition, there are about 120000 Turkish Cypriots living in Britain (Onal, 2003). This population is a young one: one-third of the community in Europe is made up of eighteen year olds and under, most of whom were born and raised

1 The Turkish-speaking community in London is made up of three groups: Turks; Turkish Kurds; and Turkish Cypriots. In our detailed report, we discuss ethnic variations in relation to young people's economic prosperity and to other aspects of their lives. Here, we simply focus on the effects of transnational networks in relation to their economic prospects, since they have access to these networks regardless of ethnic background. 
in Europe (Manco, 2001: 2). Turkish speakers mainly live in the boroughs of Hackney and Haringey, north London.

The Turkish-speaking community in London is a prime example of a transnational community. When one enters a Turkish shop in Haringey, or when one learns about London's weather conditions from a Turkish television station, it is felt that the Turkishspeaking community in London is part of a 'transnational' network. Indeed, as Robins (1999) claims, a Turkish transnational community exists throughout Europe. Transnational activities tend mainly to be focused within the established boundaries of the immigrant group within a particular host society and on their country of origin, but Turkish transnationalism extends beyond the connections between the community in London and Turkey. In other words, transnationalism bonds Turkish people in different countries to each other, as well as to those in Turkey and Cyprus. The Turkish community is spread throughout Europe, the majority being located in Germany.

Young people are also engaged in transnational activities. The boundaries of the extended family network are not only within London, Turkey and Cyprus but within other countries as well, especially other European Union countries (Table 1).

Table 1 - Transnational activities among young people

\begin{tabular}{|c|c|c|c|c|c|}
\hline \multicolumn{6}{|c|}{ Having relatives in other countries } \\
\hline None (\%) & \multicolumn{2}{|c|}{$\underset{(\%)}{\text { European Union }}$} & $\begin{array}{c}\text { Outside Europe } \\
\text { (\%) }\end{array}$ & All (\%) & No. \\
\hline 34 & \multicolumn{2}{|r|}{43} & 10 & 14 & 250 \\
\hline \multicolumn{6}{|c|}{ Regular contact with relatives } \\
\hline \multicolumn{3}{|c|}{ Yes $(\%)$} & No $(\%)$ & & No. \\
\hline \multicolumn{3}{|c|}{77} & 23 & & 166 \\
\hline \multicolumn{6}{|c|}{ Television preferences* } \\
\hline \multicolumn{2}{|c|}{ Turkish TV (\%) } & British TV (\%) & \multicolumn{2}{|c|}{ Both $(\%)$} & No. \\
\hline \multicolumn{2}{|l|}{25} & 23 & & 53 & 249 \\
\hline
\end{tabular}

*Data missing in one case.

The family network in Europe is particularly close. Family members exchange information on living conditions in different European states. Table 1 shows that more than four out of ten young people have a relative in one of the European Union countries, mostly Germany, apart from Turkey and/or Cyprus. The parents of young people certainly use their transnational network to exchange information and to give support to each other.

It seems that the transnational character of the social networks of the Turkishspeaking community is followed by its members' transnational relations. When one of the relatives has a financial problem, money is collected by other members of the family 
in different countries. For instance, if one of the relatives wants to open a shop, he or she usually asks for a loan from relatives living in different countries. They also send gifts to each other and participate in special ceremonies, such as weddings. All these information exchanges create an informal knowledge network between the members of a transnational community. For example, during the fieldwork, a father talked about his relatives' hospital experiences in Germany, how they were given wrong prescriptions and how they were treated badly by inexperienced doctors. He argued that members of the community in Germany were used by the German medical system during operations to teach medical students. Additionally, one mother compared in detail the attitudes of German and British social services towards the mistreatment of children, while one kebab shop owner talked about the regulations in other European countries involved in opening a shop. These are just a few examples of how an informal information network operates in the community.

Most importantly, young people are directly engaged in these activities. Young people seem to have contact not only with relatives in Turkey or Cyprus but also with those in other countries. Table 1 shows that almost eight out of ten young people have regular contact with their relatives. The majority of these contacts usually take place through telephone or e-mail. Young people also evaluate conditions in the transnational field through this network.

Young people's engagement with the Turkish media is also important in showing the extent of their transnational activities. The availability of such media has become possible with new technologies and, in this sense, their existence makes transnational interaction more extensive. There are several Turkish-speaking local radio stations in London, but Turkish television programmes and newspapers are also important parts of ordinary Turkish-speaking family life. All the young people in the sample have a satellite dish in their home, accessing mainly Turkish channels. A few households watch other international channels, such as Sky TV or MTV. The television set is switched on first thing in the morning and switched off last thing in the evening. It is the background to daily tasks and family gatherings, while television stations always find transmission in most community organisations, coffee shops, etc. There are around 25 television channels available for Turkish people across Europe (Aksoy and Robins, 2000), offering a variety of programmes from music, movies and news to sport.

The young generation does not prefer to watch mainly Turkish television: Table 1 shows that 25 per cent of Turkish-speaking young people watch Turkish television stations only, while 53 per cent watch both British and Turkish stations. On the other hand, this table shows that, in one way or another, young people are also familiar with the transnational Turkish media. For instance, they record songs from the most popular programmes on to their mobile phones, or they consider examples from popular characters in television series during their daily discussions. Some young people even seem to be more engaged in Turkish political life than in the British one. When Mesut, a 19year-old, was asked about political parties, he automatically thought of those in Turkey although he did not prefer any of them because old leaders were still in charge and they were not capable of handling the economy. We asked him about British politics, but he showed little interest. When we asked why, he said that his only involvement with 
politics was through news on TV and it was Turkish news programmes that were watched at his home.

Overall, Turkish-speaking young people's direct engagement with transnational social activities is intense. They have regular contact with their relatives outside Britain and they follow Turkish media through satellite connections. In fact, these transnational engagements might encourage some young people to consider alternative employment opportunities offered transnationally: four in ten young people thought positively of employment alternatives outside Britain. These employment alternatives were not only in Turkey or Cyprus; they occurred across the transnational field and in a variety of countries, including Germany and France.

Young people did not choose these countries randomly. Having relatives nearby seems to play an important role in deciding whether young people want to move outside London. In other words, young people who decide to work outside London usually choose a country where most of their relatives were living. Sixty five per cent of young people who prefer to work in European countries also have relatives in these countries. One of them is Hasan, who said:

I can go to Germany, France or Holland for work. I have relatives in all these countries. I have already been there.

It seems that young people gather the necessary information through their relatives in the transnational field. Unfortunately, some of the information might not be encouraging as regards the creation of an employment opportunity. For example, Bengi evaluated the employment conditions in different European Union countries on the basis of her relatives' experiences there:

My uncle has been in Holland for about 30-35 years. His daughter finished at the university there and then took a Masters degree. Yet employers insisted that her language skills were not good enough. Yet at the end we are second class. This is clear... My other uncle works as a civil servant in Norway. He finished at a University in Turkey. He knows three languages and works as a translator. He said that it doesn't matter how many languages you can speak or how professional you are, they can make you feel that you are not one of them.

Moreover, young people also gathered ideas on employment and living conditions in the Turkish transnational field through the media. During the fieldwork, there was an economic crisis in Turkey in which plenty of people lost their jobs and most small companies were declared bankrupt. Nazim explained how the news in the television programmes affected him:

When you watch television, you can see how the politicians acted carelessly and how messy their politics are. Because of them lots of people suffered. The politicians only think of themselves and their families. They don't create new jobs for young people. The lucky ones who manage to find a job could not earn enough money and they could not complain because there are lots of others wishing to replace them. 
It seems that transnational activities offer an opportunity to these young people to learn about employment conditions in this field. In other words, transnational engagements make these young people more conscious of their choices. After an evaluation of the advantages and disadvantages, some young people were quite willing to move outside Britain. In that sense, it is important to discuss the potential of transnational networks to raise the economic aspirations of second generation young people. The following section analyses this issue in detail.

Could the transnational social field offer optimism to young Turkish-speaking people?

Turkish-speaking young people have common ideas of success and seem optimistic about their future. Other studies of young people show similar findings (Fenton et al. 2001; McDowell, 2001). When their future aspirations were questioned in our survey, only three out of ten young people had no idea, while 41 per cent wanted to have a professional job in ten years time. Twenty two per cent believed they would be in unskilled or semi-skilled jobs in the future, while six per cent saw themselves as having clerical jobs (Table 2).

When their concept of success was examined, having a good job, a house, a car and a family were cited over and over again by young people. The majority does not want to be rich, but people do aspire to have a sufficient life.

It was mentioned at the outset that some researchers believe that transnational engagements might act as a counterweight to some of the negative effects of assimilation by offering economic alternatives (Portes, 1999). Turkish-speaking young people are indeed aware of employment alternatives in the Turkish transnational network through their contacts with relatives and the media. On the other hand, being aware of some economic alternatives might not necessarily affect these young people's future economic aspirations directly. In other words, the transnational network might not push these young people's future hopes higher.

In this context, we have analysed the relationship between transnational engagements and young people's future job preferences. It seems that engaging in transnational activities does not make young people more certain of their future economic prospects. Table 2 shows that 31 per cent of young people engaging in at least one of the identified transnational activities (having contact with relatives or watching Turkish TV) acknowledged that they did not know their future aspirations, a figure which is not so different to those who did not engage in any transnational activities, where 29 per cent were not clear of their future aspirations. Furthermore, Table 2 also shows that young people who did not have transnational engagements were more likely than those who did have them to hold a professional job. This could easily be interpreted in the sense of the potential of transnational engagements to discourage young people from becoming more optimistic about the future. However, this might well be only a part of the picture. In reality, transnational networks may be able to help young people widen their horizons only where certain conditions are satisfied. 
Table 2 - Aspiration for the near future via engagement in transnational activities

\begin{tabular}{|l|l|c|c|c|}
\hline \multicolumn{2}{|c|}{} & \multicolumn{2}{|c|}{$\begin{array}{c}\text { Engagement in } \\
\text { transnational activities }\end{array}$} & \\
\cline { 3 - 5 } \multicolumn{2}{|c|}{} & Yes (\%) & No (\%) & All (\%) \\
\hline \multirow{3}{*}{$\begin{array}{l}\text { Aspiration for the } \\
\text { near future }\end{array}$} & Don't yet know & 31 & 29 & 31 \\
\cline { 2 - 5 } & Unskilled/semi-skilled work & 24 & 12 & 22 \\
\cline { 2 - 5 } & Clerical/office work & 6 & 3 & 6 \\
\cline { 2 - 5 } & Professional work & 39 & 56 & 41 \\
\hline \multirow{2}{*}{ Total } & & $\begin{array}{c}100 \% \\
(211)\end{array}$ & $100 \%(34)$ & $\begin{array}{c}100 \% \\
(245)\end{array}$ \\
\hline
\end{tabular}

Data missing in five cases

In this context, we have adopted a univariate analysis of variance in order to find statistically relevant connections between young people's economic aspirations and other variables, including transnational engagements (Table 3). Transnationalism was tested together with gender, age, education degree, fathers' economic status and being born in Britain to analyse any possible significant effect on young people's economic aspirations. Statistical significance was set at five per cent in all analyses. 
Table 3 - Tests of effects between subjects

Dependent variable: Aspirations for the near future

\begin{tabular}{|c|c|c|c|c|c|}
\hline Source & $\begin{array}{l}\text { Type III } \\
\text { sum of } \\
\text { squares }\end{array}$ & Df & $\begin{array}{l}\text { Mean } \\
\text { square }\end{array}$ & $\mathbf{F}$ & Sig. \\
\hline Corrected model & $171,149^{a}$ & 79 & 2,166 & 1,485 & .018 \\
\hline Intercept & 399,144 & 1 & 399,144 & 273,609 & .000 \\
\hline $\mathrm{Age}^{\mathrm{b}}$ & 6,711 & 2 & 3,356 & 2,300 & .103 \\
\hline Gender & .433 & 1 & .433 & .297 & .586 \\
\hline Born in Britain & 1,611 & 1 & 1,611 & 1,104 & .295 \\
\hline Diplomac $^{c}$ & 3,959 & 2 & 1,979 & 1,357 & .260 \\
\hline Father's occupation ${ }^{\mathrm{d}}$ & 2,917 & 2 & 1,459 & 1,000 & .370 \\
\hline $\begin{array}{l}\text { Transnational } \\
\text { engagements }\end{array}$ & 2,398 & 1 & 2,398 & 1,644 & .202 \\
\hline $\begin{array}{c}\text { Bornbrit* } \\
\text { transnationalisme }\end{array}$ & 6,264 & 1 & 6,264 & 4,294 & .040 \\
\hline Error & 240,704 & 165 & 1,459 & & \\
\hline Total & 2037,000 & 245 & & & \\
\hline Corrected Total & 411,853 & 244 & & & \\
\hline
\end{tabular}

a. $R$ Squared $=.416$ (Adjusted $R$ Squared $=.136)$

b. Age categories: 16-17; 18-20; and 21-23

c. Diploma categories: no qualifications; GCSEs or GNVQs; and A-Levels.

d. Fathers' occupation categories: unemployed or retired; unskilled or semi-skilled employment; and self-employment or professional.

e. Apart from the combined effect, the pair of transnationalism and being born in Britain seems to be effective.

Table 3 shows that all the variables had a combined effect on the economic aspirations of young people (significance for corrected model: 0.018 and, for the intercept: $0.000(<0.05)$ ), while none of them alone had a significant effect (significance of age: 0.103; gender: 0.586; being born in Britain: 0.295; diploma: 0.260; father's occupational status: 0.370; and transnational engagements: $0.202(>0.05))$. In other words, even if some young people have transnational links, this does not give them equal access to the advantages of being transnational in terms of their future economic prospects, or vice versa. In terms of being transnational, a significant effect may depend on young people's social and economic status.

In fact, the importance of social and economic factors has been pointed out in other studies of transnationalism (Mahler, 1998; Guarnizo and Smith, 1998; Guarnizo et al. 
1999; Van Hear, 1998; Roberts et al. 1999). For instance, in their study of the transnational activities of Colombian migrants, Guarnizo and Diaz (1999: 417) found that Colombian transnational activities were not as boundless as transnational researchers advocate:

They (transnational processes) do not overcome class, racial and regional differences, categories which remain significant analytical tools for the analysis of transnational migration in general.

The main idea advocated by researchers is that, before reaching concrete conclusions, it is important to investigate what are the transnational activities concerned; how representative they are of the entire transnational field; and the extent to which the participants in such activities are representative of the entire migrant population. In that sense, studies in this area should also investigate in more detail the role of gender, class, age and mobility (Mahler, 1998).

Consequently, it is important to pay particular attention to the socio-economic status of young people as regards their age, gender and educational qualifications, and the economic status of their family, etc. when the influence of transnational engagements on their future economic aspirations is being examined. Moreover, according to Table 3 , the pair of transnational engagements and being born in Britain has a particularly significant influence on young people's economic aspirations. Indeed, most young people who were born in Turkey and who only came later to Britain are asylum seekers and refugees, meaning that they do not have the formal citizenship rights held by others. This situation brings insecurity and uncertainty to their lives, leading people to want to secure their life in Britain as a first priority. In the future, they might be keener to explore transnational alternatives outside Britain, with these potentially then having a significant effect as regards boosting their hopes for their future. For instance, 16-yearold Figen, as a refugee, did not think herself in a position to utilise transnational engagements in order to secure more stable employment in the future. Stability in her life could only be bought by first securing British citizenship.

This also became clearer during the focus group discussions with young people, who think that moving to other countries is a possibility if they fail to be allowed to remain in Britain. Most of them have relatives in Europe, so they want to go to one of the other European countries - which, of course, is quite difficult in practice if they are not British nationals or nationals of another EU country.

On the other hand, most young people who have citizenship rights have high aspirations since they feel more secure in this country. The result is that they can afford to be more cautious and selective in terms of employment opportunities in the transnational field. For instance, Alpay, a sixteen-year-old Cypriot boy, wanted to be a radio or television presenter in ten years time and had considered moving away from London:

If it's something that wasn't much better than what I'm already doing then I wouldn't do it because it's leaving everyone behind as well. It's got to be worth it. It's got to be a hundred per cent worth it. 
Indeed, unlike refugees and asylum seekers, young people who were able to travel to Turkey and Cyprus for a holiday, or for other reasons, felt more comfortable in looking for a job in Turkey. Twenty-year-old Sinem wanted to hold a professional job in the future and was interested in a PR (public relations) job in Samsun (a city in the Black Sea region of Turkey). Her cousin's husband was a football player in Samsunspor, a sporting club there, and he had introduced Sinem to the manager during a visit she had made a few months previously. In Britain, she has found many different jobs so far including on a local newspaper, in an office, etc. and she is seriously considering this job offer in Samsun since the job involves a lot of travelling and opportunities for job satisfaction. She will have many family members around her - since her family already have a home in Samsun - and will earn a good salary. It is also important for her that she could leave at any time and come back to Britain, since she has both British and Turkish passports. It is clear that having a family network is essential for Sinem to find a job in Turkey but, in order to commit fully, the nature of the employment and having alternative options, like coming back to Britain, are also important.

The importance of citizenship for migrants is also mentioned in other transnationalism studies. For instance, in a study of the relationship between transnational activities and the integration of migrants in Germany and Denmark, the role of dual citizenship as a transnational feature is discussed as a means of improving the political participation of migrants in the host societies (Avc1, 2006: 67-84). Consequently, it could be argued that the effect of transnational engagements on young people's future employment aspirations is possible for those young people who are able to move around the transnational field.

\section{Conclusion}

In this article, we have tried to analyse some of the effects of the transnational field on young people's economic prospects, discussing the potential of this field in widening young people's horizons. In this respect, this study aimed to establish the importance of transnational activities for Turkish-speaking young people in relation to their future economic ambitions. On the other hand, this article has also argued that the effects of transnationalism are more complex and only observable when other socio-economic factors are also taken into consideration in respect to future economic ambitions.

The Turkish-speaking community is, as we have discussed, a typical example of transnational communities. Turkish-speaking young people have strong contacts with their relatives beyond London and regularly watch Turkish television channels. Through the Turkish transnational field, these young people have information about employment conditions and opportunities outside Britain, and they also have family networks which can provide a helpful hand to them in their life outside Britain. This extensive network, furthermore, gives them the chance to compare employment conditions in different countries.

Young people have various sources of information about employment opportunities. The media, especially television, is part of a community network that extends beyond Britain and has the capacity to highlight various alternatives in different countries. Young people evaluated their existing conditions and transnational alternatives in conjunction, with some of them going on to consider employment alternatives in this 
field. That might well act to push some young people's future hopes higher. However, transnational alternatives would best serve those who were already the most advantaged according to their family backgrounds, their citizenship status or their educational qualifications.

In that sense, we can say that their future aspirations reflect realistic choices between possible alternatives. There is a complex relationship between these young people and the set of transnational activities with which they may engage. At the same time, it is clear that young people's involvement in transnational activities produces different attitudes towards employment alternatives in the future. Any employment opportunity in the transnational field does not necessarily provide an alternative in each situation.

We do need to be more cautious and to look more thoroughly at the socio-economic opportunities offered in the transnational field. At the same time, we need to consider that the relationship between young people's aspirations and their engagements in the transnational field is not straightforward. Apart from engaging in transnational activities, there are many factors such as gender, age and educational achievement which influence young people's aspirations. In that sense, transnational engagements could be an alternative way to improve the conditions of migrants in general - and second generation ones in particular - if other socio-economic factors are taken into account.

\section{References}

Aksoy, Asu and Kevin Robins (2000) 'Thinking across spaces: Transnational television from Turkey’ European Journal of Cultural Studies 3(3): 343-365.

Avc1, Gamze (2006) 'Comparing Integration Policies and Outcomes: Turks in the Netherlands and Germany’ Turkish Studies 7(1): 67-84.

Basch, Linda et al. (1994) Nations Unbound - Transnational Projects, Postcolonial Predicaments and Deterritorialized Nation-States Australia: Gordon and Breach Publishers.

Cohen, Robin (1997) Global Diasporas - An Introduction London: UCL Press.

Enneli, P, T. Modood and H. Bradley (2005) Young Turks and Kurds - A set of 'invisible' disadvantaged groups York: Joseph Rowntree Foundation.

Evergeti, Venetia and Elisabetta Zontini (2006) 'Introduction: Some critical reflections on social capital, migration and transnational families' Ethnic and Racial Studies 29(6): 1025-1039.

Fenton, S et al. (2001) In and Out of Work: Job Changing, Life Changing and Young Adult Identities unpublished paper presented at International Sociological Association, Helsinki, August.

Fernandez-Kelly, Patricia and Lisa Konczal (2005) 'Murdering the Alphabet: Identity and entrepreneurship among second generation Cubans, West Indians and Central Americans' Ethnic and Racial Studies 28(6): 1153-1181.

Gillespie, Marie (1995) 'Sacred Serials, devotional viewing and domestic worship - A case study in the interpretation of two TV versions of the Mahabharata in a Hindu 
family in west London' in Robert C. Allen (Ed.) To Be Continued... Soap operas around the world London: Routledge, pp. 354-380.

Goldring, Luin (1998) 'The Power of Status in Transnational Social Fields' in Michael Peter Smith and Luis E. Guarnizo (Eds.) Transnationalism from Below New Brunswick: Transaction Publishers, pp. 165-195.

Gubta, Akhil and James Ferguson (1992) 'Beyond Culture: Space, Identity and the Politics of Difference' Cultural Anthropology 7: 6-23.

Itzigsohn, J et al. (1999) 'Mapping Dominican transnationalism: narrow and broad transnational practices' Ethnic and Racial Studies 22(2): 316-339.

Louie, Vivian (2006) 'Growing Up Ethnic in Transnational Worlds: Identities among Second-Generation Chinese and Dominicans' Identities: Global Studies in Culture and Power 13: 363-394.

Manco, U (2001) Turks In Western Europe http://allserv.rug.ac.be/ hdeley/umanco3.htm.

McDowell, L (2002) Redundant Masculinities Oxford: Blackwell.

Onal, A (2003) İngiltere'deki Türkiyeli topluluk üstüne bir çalışma-1 ve 2.25 and 26 July http://www.gazetem.net/bellekyazi.asp?yaziid=67 and http:// www.gazetem.net/bellekyazi.asp?yaziid $=68$.

Portes, A (1999) 'Conclusion: Towards a new world - the origins and effects of transnational activities' Ethnic and Racial Studies 22(2): 463-477.

Portes, A (2001) Transnational Entrepreneurs: The Emergence and Determinants of an Alternative Form of Immigrant Economic Adaptation WPTC-01-05, http:// www.transcomm.ox.ac.uk/working\%20papers/WPTC-01-05 \%20Portes.pdf.

Portes, A et al. (1999) 'The Study of Transnationalism: Pitfalls and Promise of an Emergent Research Field' Ethnic and Racial Studies 22(2): 217-237.

Reynolds, Tracey (2006) 'Caribbean families, social capital and young people's diasporic identities’ Ethnic and Racial Studies 29(6): 1087-1103.

Robins, Kevin (1999) 'Negotiating Spaces: Media and Cultural Practices in the Turkish Diaspora in Britain, France and Germany' http://www.transcomm.ox.ac.uk/wwwroot/robins.htm.

Schiller, Nina et al. (1999) 'Terrains of blood and nation: Haitian transnational social fields' Ethnic and Racial Studies 22(2): 340-366.

Sen, F, Y. Ulusoy and C. Şentürk (2008) 'Almanya ve Avrupa Birliği’nde Türk Girişimciliği’ Uluslararası Sosyal Araştırmalar Dergisi 1/2: 405-418.

Uras, G (2002) 'Bitmeyen Goc’ Milliyet 24 October.

Vertovec, Steven (1999) 'Conceiving and Researching Transnationalism' Ethnic and Racial Studies 22(2): 447-462. 
Vertovec, Steven (2001) Transnational Challenges to the 'New' Multiculturalism unpublished paper presented at the ASA Conference held at the University of Sussex, 30 March-2 April.

Vertovec, Steven (2002) Transnational Networks and Skilled Labour Migration paper presented at the following conference: Ladenburger Diskurs 'Migration', GottliebDaimler- und Karl-Benz-Stiftung, Ladenburg, 14-15 February, WPTC-02-02, http://www.transcomm.ox.ac.uk/working\%20papers/WPTC-01-05 \%20Portes.pdf.

Zhou, Min (2004) 'Revisiting Ethnic Entrepreneurship: Convergencies, Controversies and Conceptual Advancements’ International Migration Review 38(3): 1040-1074.

\section{Acknowledgements}

I would like to thank the Joseph Rowntree Foundation for sponsoring the research on which this article is based. Tariq Modood's and Harriet Bradley's contributions on this research are also appreciated. I would also like to thank the young people, their families and community organisations: without their support and involvement, this research would not have been conducted. I would finally like to thank Sara Tonge for generously helping to revise the article's English. 